Article

\title{
Effects of Pr and Yb Dual Doping on the Thermoelectric Properties of $\mathrm{CaMnO}_{3}$
}

\author{
Cuiqin $\mathrm{Li}^{1}$, Qianlin Chen ${ }^{1,2, *}$ and Yunan Yan $^{3}$ \\ 1 School of Chemistry and Chemical Engineering, Guizhou University, Guiyang 550025, China; \\ licq2345@163.com \\ 2 National \& Local Joint Laboratory of Engineering for Effective Utilization of Regional Mineral Resources \\ from Karst Areas, Guiyang 550025, China \\ 3 School of Physics and Optoelectronic Engineering, Ludong University, Yantai 264025, China; \\ yunan@ldu.edu.cn \\ * Correspondence: cq11018@163.com; Tel.: +86-138-8518-1709
}

Received: 5 September 2018; Accepted: 19 September 2018; Published: 23 September 2018

\begin{abstract}
There has been research on $\mathrm{CaMnO}_{3}$ with natural abundance, low toxicity, and low cost as promising candidates for n-type thermoelectric (TE) materials. In this paper, $\mathrm{Ca}_{1-2 \mathrm{x}} \mathrm{Pr}_{\mathrm{x}} \mathrm{Yb}_{\mathrm{x}} \mathrm{MnO}_{3}$ with different $\mathrm{Pr}$ and $\mathrm{Yb}$ contents $(\mathrm{x}=0,0.01,0.02,0.03,0.04$ and 0.05$)$ were synthesized by means of coprecipitation. With X-ray diffraction (XRD), scanning electron microscopy (SEM), and high-resolution transmission electron microscopy (HRTEM), researchers characterized the phase structure and morphology of all the samples. The oxidation states of manganese were determined by X-ray photoemission spectroscopy (XPS). The role of Ca-site dual doping in the TE properties was also investigated. Increasing the $\mathrm{Pr}$ and $\mathrm{Yb}$ contents leads to decreases in the electrical resistivity and Seebeck coefficient, leading to a power factor of $3.48 \times 10^{-4} \mathrm{~W} \cdot \mathrm{m}^{-1} \cdot \mathrm{K}^{-2}$ for $\mathrm{x}=0.04$ at $773 \mathrm{~K}$, which is its maximum. Furthermore, the thermal conductivity $(\kappa)$ decreases with increasing $x$, and $\kappa=1.26 \mathrm{~W} \cdot \mathrm{m}^{-1} \cdot \mathrm{K}^{-1}$ is obtained for $\mathrm{x}=0.04$ at $973 \mathrm{~K}$. $\mathrm{Ca}_{0.92} \operatorname{Pr}_{0.04} \mathrm{Yb}_{0.04} \mathrm{MnO}_{3}$ exhibit a ZT (thermoelectric figure of merit) value of 0.24 at $973 \mathrm{~K}$, approximately 3 times more than that of the pristine $\mathrm{CaMnO}_{3}$. Thus, the reported method is a new strategy to enhance the TE performance of $\mathrm{CaMnO}_{3}$.
\end{abstract}

Keywords: dual doping; $\mathrm{CaMnO}_{3}$; coprecipitation method; thermoelectric properties

\section{Introduction}

The rapid growth and substantial increase in human energy demand has become a global problem of the twenty-first century. Reserves of fossil fuels such as coal, petroleum and natural gas are becoming increasingly depleted. Improvements in the comprehensive utilization of existing technologies, the development of current energy sources and the identification of new renewable energy sources are urgently needed [1]. Due to the generation of large amounts of waste heat across the world whichpollutes the environment, the conversion of waste heat into useful energy is an attractive target. Thermoelectric (TE) devices are considered promising candidates because they can directly convert waste heat into electrical energy [2]. Both n-type and p-type TE materials are superior in terms of simplicity, safety, stability, lack of moving parts, and no maintenance, leading to widespread interest in recent years [3,4].

The energy conversion efficiency of TE materials is calculated by a figure of merit, ZT ( $\left.=\mathrm{S}^{2} \mathrm{~T} / \rho \kappa\right)$, in which $S$ refers to the Seebeck coefficient, $\rho$ refers to the electrical resistivity, T refers to the working temperature in Kelvin, and $\kappa$ refers to the thermal conductivity [5]. Both a high-power factor $(\mathrm{PF})\left(\mathrm{S}^{2} / \rho\right)$ and a low value of $\kappa$ are required for practical use. Recently, improvements at the proof-of-concept level 
combined with advanced synthetic methods have resulted in alloy TE materials with ZT values higher than 2 [6-10]. However, the disadvantages of high cost, toxicity and weak thermal stability severely restrict the application of these alloys as good TE materials. Therefore, oxide thermoelectric materials as promising high-temperature materials with structural and chemical stability, oxidative resistance, environmental friendliness and low cost have received increasing attention. Among the oxide TE materials, n-type $\mathrm{CaMnO}_{3}$ have received increasing attention owing to their high Seebeck coefficient $(-550 \mu \mathrm{V} / \mathrm{K})$ [11]. The electrical resistivity and thermal conductivity of these oxide materials, however, are too high for TE applications. Numerous efforts, such as doping the Ca site with different high-valent cations, have been devoted to improving the TE properties of $\mathrm{CaMnO}_{3}$. The effect of high-valent cation addition on the TE properties of $\mathrm{CaMnO}_{3}$ was first investigated by $\mathrm{M}$. Ohtaki et al. The researchers found that $\mathrm{Ca}_{0.9} \mathrm{Bi}_{0.1} \mathrm{MnO}_{3}$ exhibited a maximum $\mathrm{PF}$ of $2.8 \times 10^{-4} \mathrm{~W} \cdot \mathrm{m}^{-1} \cdot \mathrm{K}^{-2}$ at $1073 \mathrm{~K}$ and showed a large ZT value of 0.085 [12]. Based on that study, the introduction of high-valent lanthanides at the Ca site was frequently reported to increase the charge carrier concentration through forming $\mathrm{Mn}^{3+}$ in the $\mathrm{Mn}^{4+}$ matrix, which is in accordance with electron doping in the eg states. Moreover, the enormous mass difference between rare-earth $(\mathrm{RE})^{3+}$ and $\mathrm{Ca}^{2+}$ ions was expected to reduce the thermal conductivity. Therefore, the conversion efficiency improved. Substitution with lanthanides at the Ca site was reported by D. Flahaut et al., and Y. Wang et al. For samples with lanthanide doping concentrations higher than $10 \%$ at the Ca site prepared through a solid-state method, the resistivity, which was found to depend on the RE size, exhibited a minimum for $\mathrm{Yb}$ substitution [13-15], whereas the absolute values for both the Seebeck coefficient and the thermal conductivity decreased relative to those of undoped $\mathrm{CaMnO}_{3}$, with maxima of $\mathrm{ZT}=0.16$ and $\mathrm{ZT}=0.2$, respectively, at $\mathrm{T}=1000 \mathrm{~K}$ for $\mathrm{Ca}_{0.9} \mathrm{Yb}_{0.1} \mathrm{MnO}_{3}$. Substitution of $\mathrm{Pr}^{3+}$ in $\mathrm{Ca}_{1-\mathrm{x}} \mathrm{Pr}_{\mathrm{x}} \mathrm{MnO}_{3}$ was also reported to enhance the TE performance, with $\mathrm{ZT}=0.16$ at $873 \mathrm{~K}$ for $\mathrm{x}=0.08$ [16] or at $1100 \mathrm{~K}$ for $\mathrm{x}=0.14$ [17]. However, dual doping of the Ca sites of $\mathrm{CaMnO}_{3}$ has proven to be more effective at promoting TE properties [18-20]. The TE performance of $\mathrm{CaMnO}_{3}$ dual-doped with $\mathrm{R}^{3+}$ elements was originally proposed by A. Kosuga et al. [21], while subsequent studies of doping with other $\mathrm{R}^{3+}$ ions were carried out by C.M. Kim and H.C. Wang [22,23]. The researchers found that the resistivity and Seebeck coefficient were both reduced by the introduction of multiple elements at the Ca site. In addition, the thermal conductivity, which was affected by both crystal distortion and the tremendous difference in mass between $\mathrm{Ca}^{2+}$ and $\mathrm{R}^{3+}$ ions, was also reduced [21]. All the $\mathrm{CaMnO}_{3}$ mentioned above were synthesized through a solid-state method. However, the coprecipitation method exhibits many advantages over the conventional solid-state method. The mixed nitrate precursors are dissolved in water in advance, enabling the dopants to be better dispersed in matrix materials and powder, leading to a narrow particle distribution and microstructural homogeneity of the sintered product. Romy Löhnert et al., found that $\mathrm{Ca}_{0.96} \mathrm{Gd}_{0.04} \mathrm{MnO}_{3}$ synthesized by a coprecipitation method had a narrow particle distribution and small particle size, and they exhibited a much lower thermal conductivity than prepared by the conventional solid-state method. The highest observed ZT value was 0.14 , which was found at $973 \mathrm{~K}$ for the $\mathrm{Ca}_{0.96} \mathrm{Gd}_{0.04} \mathrm{MnO}_{3}$ prepared by the coprecipitation method; this value was 1.5 times larger than the one obtained for the sample produced through the solid-state method [24].

In the present paper, $\mathrm{Ca}_{1-2 \mathrm{x}} \mathrm{Pr}_{\mathrm{x}} \mathrm{Yb}_{\mathrm{x}} \mathrm{MnO}_{3}$ with different $\mathrm{Pr}$ and $\mathrm{Yb}$ contents $(\mathrm{x}=0,0.01,0.02,0.03$, 0.04 and 0.05 ) were fabricated for the first time by coprecipitation. The effects of $\mathrm{Pr}$ and $\mathrm{Yb}$ substitution on the microstructure and TE properties were investigated. Possible mechanisms were also explored. In addition, the effects of $\mathrm{Pr}$ and $\mathrm{Yb}$ dual doping on $\mathrm{CaMnO}_{3}$ system density of states (DOS) were investigated using first-principles calculations to better understand the TE properties of the $\operatorname{Pr}$ and $\mathrm{Yb}$ dual-doped $\mathrm{CaMnO}_{3}$ system. 


\section{Materials and Methods}

\subsection{Sample Synthesis}

Polycrystalline samples of $\mathrm{Ca}_{1-2 \mathrm{x}} \mathrm{Pr}_{\mathrm{x}} \mathrm{Yb}_{\mathrm{x}} \mathrm{MnO}_{3}(\mathrm{x}=0,0.01,0.02,0.03,0.04$ and 0.05$)$ were prepared by a coprecipitation process in which $\mathrm{Ca}\left(\mathrm{NO}_{3}\right)_{2} .4 \mathrm{H}_{2} \mathrm{O}$ (purity $\left.99.95 \%\right), \mathrm{Mn}\left(\mathrm{NO}_{3}\right)_{2}$ solution $(50 \%, w / w)$, $\mathrm{Yb}\left(\mathrm{NO}_{3}\right)_{3} \cdot 6 \mathrm{H}_{2} \mathrm{O}, \mathrm{Pr}\left(\mathrm{NO}_{3}\right)_{3}$ and $\mathrm{NH}_{4} \mathrm{HCO}_{3}$ were used as raw materials. $\mathrm{Ca}\left(\mathrm{NO}_{3}\right)_{2}, \mathrm{Mn}\left(\mathrm{NO}_{3}\right)_{2}$ solution, $\operatorname{Pr}\left(\mathrm{NO}_{3}\right)_{3}$ and $\mathrm{Yb}\left(\mathrm{NO}_{3}\right)_{3}$ powder were mixed in stoichiometric ratios and dissolved in distilled water to prepare the nitrate stock solution. Next, excess $\mathrm{NH}_{4} \mathrm{HCO}_{3}$ (purity $99.99 \%$ ) as a precipitation agent $(20 \%, w / w)$ was added dropwise to the nitrate solution with continuous stirring and moderate heating until $\mathrm{pH}>8.5$ to completely precipitate the metal ions. The resultant suspension was subjected to suction filtration, and the collected precipitate was washed with distilled water many times before being dried at $343 \mathrm{~K}$ for $2 \mathrm{~h}$. Then, the resultant precursor powder was calcined in air at $1173 \mathrm{~K}$ for $8 \mathrm{~h}$, forming a complex precursor powder of oxide. The obtained powder was pelletized with pressure and sintered in air at $1523 \mathrm{~K}$ for $48 \mathrm{~h}$ with intermediate grinding to ensure the absence of precursor phases.

\subsection{Characterization}

The phase purity of the powder samples after sintering was studied by means of X-ray diffraction (XRD, PANalytical B.V., X'Pert PRO, Almelo, The Netherlands) with $\mathrm{Cu} \mathrm{K} \alpha$ radiation (1.5406 $\AA$ ). XRD data were obtained at $0.02^{\circ}$ intervals between $15^{\circ}$ and $120^{\circ}$. Quantitative Rietveld refinement was carried out using the FullProf program [25] for profile analysis based on the crystal structure of pure $\mathrm{CaMnO}_{3}$ proposed by H. Taguchi [26], and marokite $\mathrm{CaMn}_{2} \mathrm{O}_{4}$ was included as an additional phase, as proposed by H.G. Giesber [27]. In the refinement process, the peak reflection shapes were modelled through a pseudo-Voigt profile function corrected for asymmetry and the background by way of a linear interpolation. The refinement data were obtained by refining the following parameters: scale factors, background parameters, zero-point error, lattice parameters, half-width parameters ( $\mathrm{U}, \mathrm{V}$ and $\mathrm{W})$, atomic position parameters, peak width parameters, peak shape parameters and profile asymmetry parameters [28]. The powder samples were digested with Aqua regia, then the content of $\mathrm{Pr}^{3+}$ and $\mathrm{Yb}^{3+}$ were determined by using an inductively coupled plasma atomic emission spectrometry (Avio 200, PerkinElmer, Waltham, MA, USA). X-ray photoelectron spectroscopy (XPS) measurements were carried out on an ESCA-LAB250Xi (Thermo Scientific, Waltham, MA, USA) spectrometer with Al K $\alpha_{1,2}$ photons. A Shirley background correction was used for all spectra. Additionally, the morphology was obtained through scanning electron microscopy (SEM, JSM-6460LV, JEOL, Tokyo, Japan). To further investigate the local structure of the dual-doped particles, high-resolution transmission electron microscopy (HRTEM, Tecnai G2 F20 S-TWIN, FEI, Hillsboro, OR, USA) observations were carried out.

\subsection{Thermoelectric Properties}

The pellets obtained after sintering were chopped into pieces with a dimension of $10 \mathrm{~mm} \times 2 \mathrm{~mm} \times 2 \mathrm{~mm}$ for simultaneous measurements of electrical resistivity and Seebeck coefficient using an UlvacRiko ZEM-3 system (Yokohama, Japan). The disc-shaped pellets were all polished to a diameter of $12.7 \mathrm{~mm}$ and a thickness of $2 \mathrm{~mm}$ to determine both the thermal diffusivity (D) with a business system (LFA-447 Nanoflash, Netzsch, Selb, Germany) and the designated heat capacity $\left(\mathrm{C}_{\mathrm{p}}\right)$ with commercial equipment (DSC 200 F3, Netzsch, Selb, Germany). The thermal conductivity was computed with the following formula: $\kappa=\mathrm{DC}_{\mathrm{p}} \mathrm{da}$. The actual density (da) of the sample pellets was obtained in accordance with the Archimedes method.

\subsection{Computational Method}

The first-principles spin-polarized calculations were carried out within the CP2K/Quickstep package [29]. As density functional theory methods tend to underestimate the band gap, we adopted Hubbard $U$ correction throughout the calculations [30]. The $U$ values corresponding to the Hubbard $\mathrm{U}$ correction of $\mathrm{Mn} 3 \mathrm{~d}$ and $\mathrm{O} 2 \mathrm{p}$ orbitals were designated as $3.9 \mathrm{eV}$ and $3.5 \mathrm{eV}$, respectively. With the 
norm-conserving Goedecker-Teter-Hutter (GTH) pseudopotentials, the core electrons of all elements were described [31]. With the use of the Gaussian function with molecularly optimized double-zeta polarized basis sets (m-DZVP), the wave functions of Ca $3 s^{2} 3 p^{6} 4 s^{2}, M n 3 s^{2} 3 p^{6} 3 d^{5} 4 s^{2}, O 2 s^{2} 2 p^{4}$, $\operatorname{Pr} 4 f^{3} 5 s^{2} 5 p^{6} 6 s^{2}$, and $Y b 5 s^{2} 5 p^{6} 6 s^{2} 4 f^{14}$ electrons were described [32]. A 500 Ry cut-off energy was applied as the auxiliary basis set for plane waves. With regard to the calculation structures, a supercell of $\mathrm{CaMnO}_{3}(\mathrm{a}=10.67 \AA, \mathrm{b}=7.57 \AA, \mathrm{c}=10.82 \AA)$ was used. To simulate the Pr and $\mathrm{Yb}$ dual-doped structure, different concentrations of $\mathrm{Ca}$ atoms were substituted by the RE elements Pr and $\mathrm{Yb}$. The Fermi level was set as the zero point in all relative calculations.

\section{Results}

\subsection{Characterization of Structure and Composition}

In Figure 1, the refined XRD patterns of the $\mathrm{Ca}_{1-2 \mathrm{x}} \mathrm{Pr}_{\mathrm{x}} \mathrm{Yb}_{\mathrm{x}} \mathrm{MnO}_{3}(\mathrm{x}=0,0.01,0.03,0.05)$ powders obtained by the coprecipitation method are presented. The main phase observed for all the samples at $298.15 \mathrm{~K}$ can be assigned to orthorhombic $\mathrm{CaMnO}_{3}$ (pdf \#89-0666, space group Pnma 62). A small amount of $\mathrm{CaMn}_{2} \mathrm{O}_{4}$ is detected $(2-5 \%)$ as a secondary phase in all the studied samples. The refined structural parameters, bond distances, distortion angles, and tolerance factor $(t)$ of the $\mathrm{Ca}_{1-2 \mathrm{x}} \mathrm{Pr}_{\mathrm{x}} \mathrm{Yb}_{\mathrm{x}} \mathrm{MnO}_{3}(\mathrm{x}=0,0.01,0.02,0.03,0.04$ and 0.05$)$ series are summed up in Table 1. The relationships between the lattice parameters, cell volume and the dual-doping composition $\mathrm{x}$ are shown in Figure 2. Table 1 and Figure 2 show that with an increase in the concentration of $\operatorname{Pr}$ and $\mathrm{Yb}$, the lattice parameters and cell volume increase monotonically, which may be illustrated through the fact that although the ionic radius of the $\mathrm{Yb}^{3+}$ doping ions $(0.985 \AA)$ is smaller than that of $\mathrm{Ca}^{2+}(1.12 \AA)$, the ionic radius of the $\operatorname{Pr}^{3+}$ doping ions $\left(1.126 \AA\right.$ ) is a litter bit larger than that of $\mathrm{Ca}^{2+}$. Furthermore, with the introduction of higher valence states $\mathrm{Pr}^{3+}$ and $\mathrm{Yb}^{3+}$ at the Ca site, $\mathrm{Mn}^{3+}$ presence is induced within the $\mathrm{Mn}^{4+}$ matrix, corresponding to charge compensation principle, and the ionic radius of $\mathrm{Mn}^{3+}$ exceeds that of $\mathrm{Mn}^{4+}\left(r\left[\mathrm{Mn}^{4+}\right]=0.530 \AA\right.$ and $\left.\mathrm{r}\left[\mathrm{Mn}^{3+}\right]=0.645 \AA\right)$ [33]. So, the increasing $\mathrm{Pr}^{3+}$ and $\mathrm{Yb}^{3+}$ concentration together with the increasing value of $\mathrm{Mn}^{3+} / \mathrm{Mn}^{4+}$ expand the lattice parameters and cell volume. This phenomenon has also been documented by Zhu et al. [34]. The following relation is also observed in Table 1 and Figure 2: $c<b / \sqrt{2}<a$, indicating the occurrence of the deformation of O-type orthorhombic of $\mathrm{Ca}_{1-2 x} \operatorname{Pr}_{\mathrm{x}} \mathrm{Yb}_{\mathrm{x}} \mathrm{MnO}_{3}$ phases, which is consistent with the results of a previous report [35].

Table 1. Refined structure parameters, bond distances, distortion angles, and tolerance factor ( $\mathrm{t}$ ) of the $\mathrm{Ca}_{1-2 \mathrm{x}} \mathrm{Pr}_{\mathrm{x}} \mathrm{Yb}_{\mathrm{x}} \mathrm{MnO}_{3}$ series.

\begin{tabular}{ccccccc}
\hline $\mathbf{C a}_{\mathbf{1}-\mathbf{2}} \mathbf{P r}_{\mathbf{x}} \mathbf{Y b}_{\mathbf{x}} \mathbf{M n O}_{\mathbf{3}}$ & $\mathbf{x}=\mathbf{0}$ & $\mathbf{x}=\mathbf{0 . 0 1}$ & $\mathbf{x = 0 . 0 2}$ & $\mathbf{x = 0 . 0 3}$ & $\mathbf{x = 0 . 0 4}$ & $\mathbf{x}=\mathbf{0 . 0 5}$ \\
\hline $\mathrm{a}(\AA)$ & $5.2808(2)$ & $5.2833(2)$ & $5.2866(2)$ & $5.2894(2)$ & $5.2931(4)$ & $5.2981(4)$ \\
$\mathrm{b}(\AA)$ & $7.4570(3)$ & $7.4595(4)$ & $7.4619(4)$ & $7.4622(3)$ & $7.4662(6)$ & $7.4698(6)$ \\
$\mathrm{b} / \sqrt{2}$ & 5.2737 & 5.2754 & 5.2771 & 5.2774 & 5.2802 & 5.2827 \\
$\mathrm{c}(\AA)$ & $5.2682(2)$ & $5.2701(2)$ & $5.2728(3)$ & $5.2754(2)$ & $5.2788(4)$ & $5.2815(4)$ \\
$\mathrm{V}\left(\AA^{3}\right)$ & 207.45 & 207.70 & 208.0 & 208.22 & 208.62 & 209.02 \\
$\mathrm{Rw}$ & 11.1 & 11.0 & 10.4 & 12.7 & 11.7 & 13.5 \\
$\mathrm{Rp}$ & 7.39 & 7.44 & 6.87 & 8.26 & 7.64 & 8.89 \\
$\chi^{2}$ & 1.74 & 1.78 & 1.68 & 2.63 & 2.32 & 3.22 \\
$\mathrm{Mn}-\mathrm{O} 2 \times 2(\AA)$ & $1.8708(2)$ & $1.8716(2)$ & $1.8728(2)$ & $1.8737(4)$ & $1.8750(4)$ & $1.8765(4)$ \\
$\mathrm{Mn}-\mathrm{O} 1 \times 2(\AA)$ & $1.9110(2)$ & $1.9117(1)$ & $1.9123(2)$ & $1.9125(2)$ & $1.9135(2)$ & $1.9144(2)$ \\
$\mathrm{Mn}-\mathrm{O} 1 \times 2(\AA)$ & $1.9281(2)$ & $1.9289(2)$ & $1.9300(2)$ & $1.9309(4)$ & $1.9322(4)$ & $1.9335(4)$ \\
$\mathrm{Mn}-\mathrm{O} 1-\mathrm{Mn}\left({ }^{\circ}\right)$ & $158.077(1)$ & $158.078(1)$ & $158.080(1)$ & $158.084(1)$ & $158.085(1)$ & $158.087(1)$ \\
$\mathrm{Mn}-\mathrm{O} 2-\mathrm{Mn}\left(^{\circ}\right)$ & $154.594(1)$ & $154.593(1)$ & $154.589(1)$ & $154.578(1)$ & $154.575(1)$ & $154.573(1)$ \\
$\mathrm{T}$ & 1.000 & 0.9982 & 1.9967 & 1.9950 & 0.9933 & 0.9916 \\
\hline
\end{tabular}



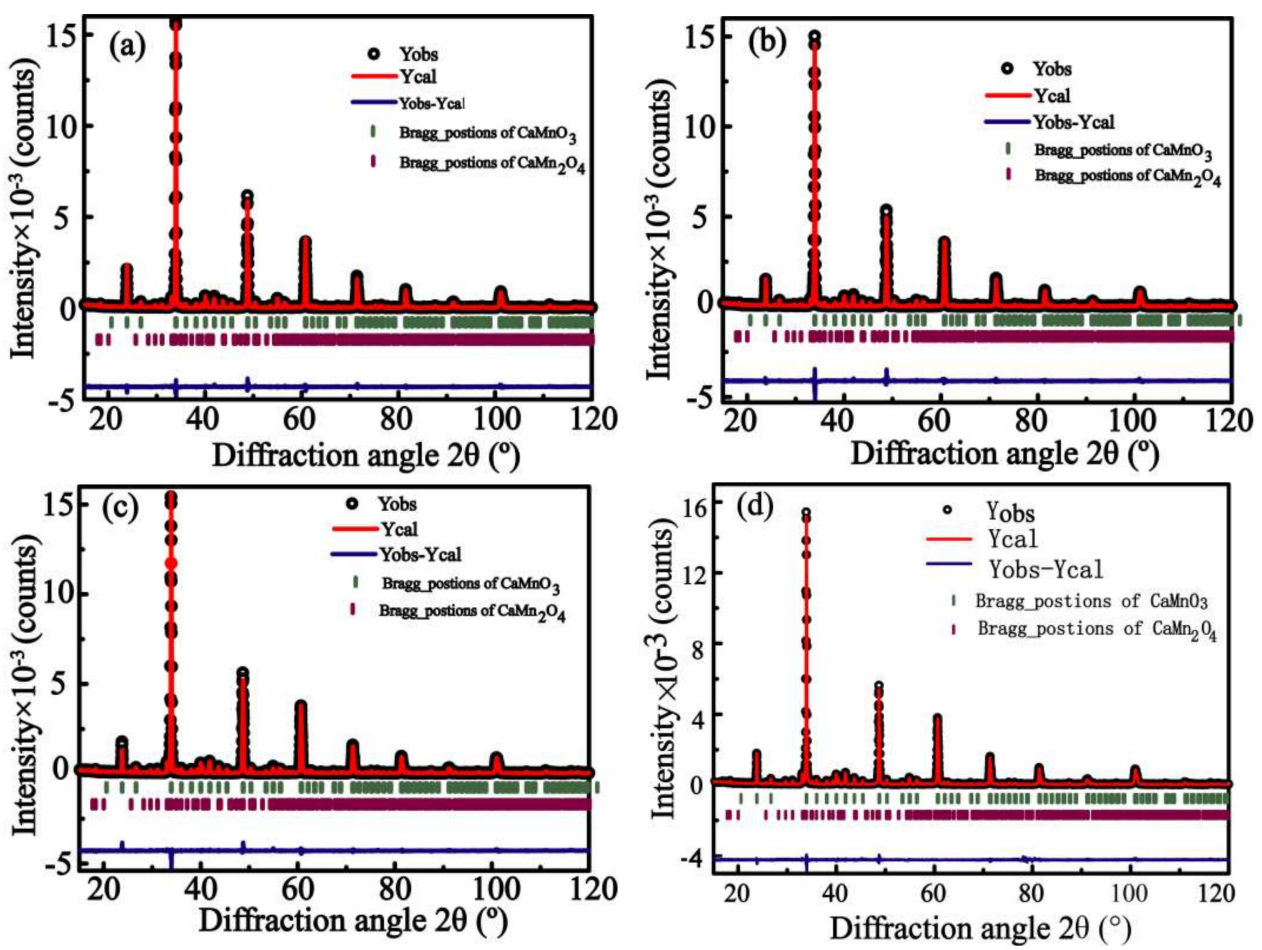

Figure 1. Observed (black circles) and calculated (red line) X-ray diffraction (XRD) patterns together with their difference curve (bottom line) after Rietveld refinement $(\lambda=1.4506 \AA$ ) for $\mathrm{Ca}_{1-2 \mathrm{x}} \mathrm{Pr}_{\mathrm{X}} \mathrm{Yb}_{\mathrm{x}} \mathrm{MnO}_{3}$. The upper reflection pattern corresponds to $\mathrm{CaMnO}_{3}$, and the lower pattern corresponds to $\mathrm{CaMn}_{2} \mathrm{O}_{4}$. (a) $\mathrm{x}=0$; (b) $\mathrm{x}=0.01 ;(\mathbf{c}) \mathrm{x}=0.03$; (d) $\mathrm{x}=0.05$.

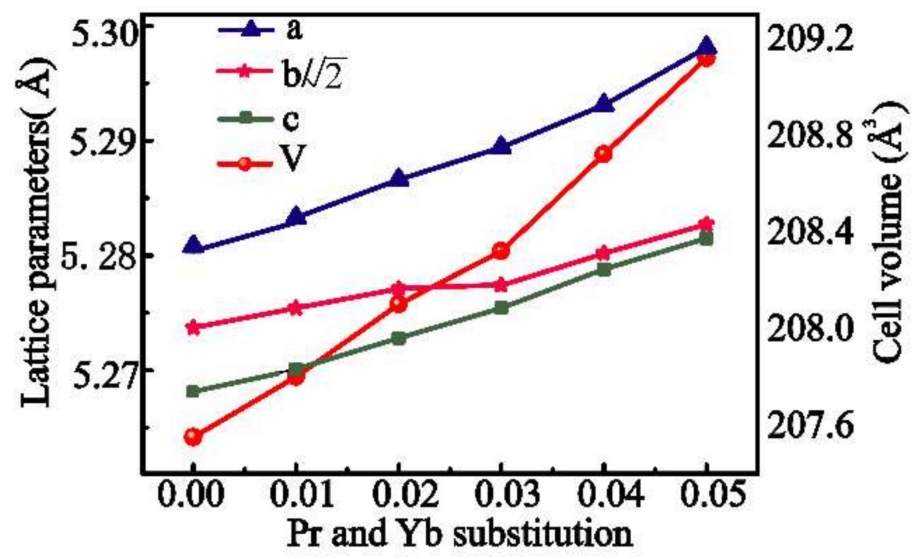

Figure 2. $\mathrm{Pr}$ and $\mathrm{Yb}$ dual-doping dependence of the lattice parameters and cell volumes of the $\mathrm{Ca}_{1-2 \mathrm{x}} \mathrm{Pr}_{\mathrm{x}} \mathrm{Yb}_{\mathrm{x}} \mathrm{MnO}_{3}$ series.

In orthorhombic perovskite-type $\mathrm{Ca}_{1-2 \mathrm{x}} \mathrm{Pr}_{\mathrm{x}} \mathrm{Yb}_{\mathrm{x}} \mathrm{MnO}_{3}(\mathrm{x}=0,0.01,0.02,0.03,0.04$ and 0.05$)$, the A-site cations ( $\mathrm{Ca}$, Pr and $\mathrm{Yb}$ ions) are coordinated to 12 anions: $8 \mathrm{O}(1)$ and $4 \mathrm{O}(2)$ ions. The B-site cations (Mn ions) are coordinated to 6 anions: $4 \mathrm{O}$ (1) (a-c plane) and $2 \mathrm{O}(2)$ ions (b axis) [36]. As seen from Table 1, the $4 \mathrm{Mn}-\mathrm{O} 1$ bond distances and $2 \mathrm{Mn}-\mathrm{O} 2$ bond distances increase with increasing $\mathrm{Pr}$ and $\mathrm{Yb}$ dual-doping content, in which the increase in the $4 \mathrm{Mn}-\mathrm{O} 1$ bond distances is larger than that in the $2 \mathrm{Mn}-\mathrm{O} 2$ bond distances because of the JahnTeller effect induced by $\mathrm{Mn}^{3+}$ [37]. This effect causes changes in the lattice parameters and eg electrons in the $\mathrm{dz}^{2}$ orbital and a-c plane of the $\mathrm{Mn}^{3+}$ centres of the $\mathrm{MnO}_{6}$ octahedron. The tolerance factor, $\mathrm{t}$, quantitatively describes the geometrical distortion of the structure, where $t=1$ represents a perfect structure of $\mathrm{ABO}_{3}$ perovskite. With regard to the $\mathrm{Pr}$ and $\mathrm{Yb}$ dual-doped phases, the tolerance factor decreases with increasing $\mathrm{Pr}$ and $\mathrm{Yb}$ substitution, indicating that the distortion of the $\mathrm{MnO}_{6}$ octahedron (The distorted $\mathrm{MnO}_{6}$ 
octahedron and geometric structure of distorted $\mathrm{MnO}_{6}$ octahedron for $\mathrm{Ca}_{0.90} \mathrm{Pr}_{0.05} \mathrm{Yb}_{0.05} \mathrm{MnO}_{3}$ are listed in Figure $3 a, b$ ) is intensified in this structure, along with the fact that the Mn-O-Mn angles measured are unequal to $180^{\circ}$. The angles of the Mn-O2-Mn bond decrease, making the band gap energy of the perovskite crystal structure change, narrowing the eg electron conduction bandwidth and resulting in improved electrical properties [38]. This result is demonstrated by the following calculated electronic structure of the dual-doped $\mathrm{CaMnO}_{3}$ series.

a

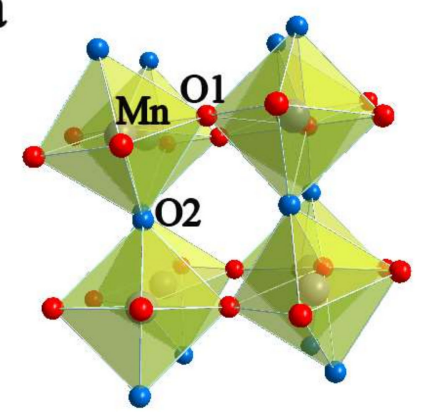

b

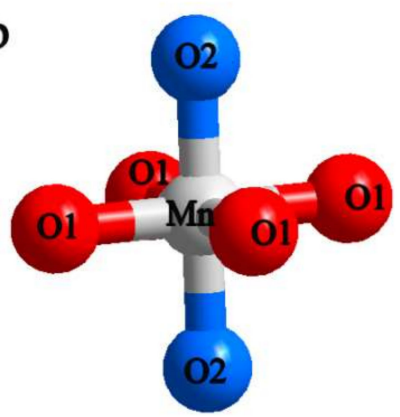

Figure 3. (a) Distorted $\mathrm{MnO}_{6}$ octahedron; (b) geometric structure of the distorted octahedron of $\mathrm{Ca}_{0.90} \operatorname{Pr}_{0.05} \mathrm{Yb}_{0.05} \mathrm{MnO}_{3}$.

Table 2 shows the results of chemical analysis, and density measurement. The theoretical density (dt) of a given sample was calculated using the following express: $d t=4 \mathrm{MW} / \mathrm{N}_{\mathrm{A}} \mathrm{V}$, where $\mathrm{MW}$, $\mathrm{V}, \mathrm{N}_{\mathrm{A}}$ is the molecular weight, the cell volume $\mathrm{V}$ (obtained from refinement) and the Avogadro's constant, respectively.

Table 2. Chemical composition (nominal and measured), and density ( $\mathrm{dt}$ and da) of $\mathrm{Ca}_{1-2 \mathrm{x}} \mathrm{Pr}_{\mathrm{x}} \mathrm{Yb}_{\mathrm{x}} \mathrm{MnO}_{3}(\mathrm{x}=0,0.01,0.02,0.03,0.04$, and 0.05).

\begin{tabular}{cccccc}
\hline $\begin{array}{c}\text { Nominal } \\
\text { Composition (x) }\end{array}$ & $\begin{array}{c}\text { Pr Content by } \\
\text { ICP }\end{array}$ & $\begin{array}{c}\text { Yb Content } \\
\text { by ICP }\end{array}$ & $\mathbf{d t}\left(\mathbf{g} / \mathbf{c m}^{\mathbf{3}}\right)$ & da $\mathbf{( g / \mathbf { c m } ^ { \mathbf { 3 } } )}$ & $\begin{array}{c}\text { Relative } \\
\text { Density (\%) }\end{array}$ \\
\hline 0 & - & - & 4.58 & 3.62 & 79 \\
0.01 & 0.0089 & 0.0078 & 4.64 & 4.08 & 85 \\
0.02 & 0.0179 & 0.0187 & 4.71 & 4.10 & 87 \\
0.03 & 0.0285 & 0.0282 & 4.78 & 4.30 & 89 \\
0.04 & 0.0388 & 0.0386 & 4.84 & 4.21 & 90 \\
0.05 & 0.0487 & 0.0483 & 4.92 & 4.38 & 89 \\
\hline
\end{tabular}

Figure 4a shows the XPS data for the Mn 2p3/2 oxidation states of $\mathrm{Ca}_{1-2 \mathrm{x}} \mathrm{Pr}_{\mathrm{x}} \mathrm{Yb}_{\mathrm{x}} \mathrm{MnO}_{3}(\mathrm{x}=0$, $0.01,0.03$ and 0.05 ). Y.G. Wei and colleagues proposed that the Mn 2p3/2 XPS binding energies for $\mathrm{Mn}^{3+}$ and $\mathrm{Mn}^{4+}$ are 641.9 and $643.2 \mathrm{eV}$, respectively [39]. To highlight these spectral differences, differentiated XPS spectra were also obtained and are shown in Figure $4 \mathrm{~b}$, in which the $\mathrm{Mn}^{3+}$ peak areas systematically increase with increasing $\mathrm{Pr}$ and $\mathrm{Yb}$ concentration in $\mathrm{Ca}_{1-2 \mathrm{x}} \operatorname{Pr}_{\mathrm{x}} \mathrm{Yb}_{\mathrm{x}} \mathrm{MnO}_{3}(\mathrm{x}=0$, $0.01,0.03$ and 0.05). This trend shows that the concentration of $\mathrm{Mn}^{3+}$ increases with increasing $\mathrm{Pr}$ and $\mathrm{Yb}$ dual doping. The obtained results show good agreement with the XRD results discussed above.

Figure 5A exhibits the typical cross-section morphology of sintered pellets of $\mathrm{Ca}_{0.90} \mathrm{Pr}_{0.05} \mathrm{Yb}_{0.05} \mathrm{MnO}_{3}$ obtained by the coprecipitation process. The same particle morphology with a narrow average particle size distribution is presented in all samples. Grains 1-5 $\mu \mathrm{m}$ in size are achieved for the coprecipitation phases in all the samples, while the grain size of the solid-state reaction-derived phases is $3-10 \mu \mathrm{m}[35,40]$, indicating that the coprecipitation process can be applied to prepare fine-grained materials. Meantime, it is found that the $\mathrm{Pr}$ and $\mathrm{Yb}$ dual-doped samples are denser than the undoped sample. Table 2 presents the relative density of all the samples. The relative density of all the Pr and $\mathrm{Yb}$ dual-doped bulk samples is higher than that of undoped sample, indicating that $\mathrm{Pr}^{3+}$ and $\mathrm{Yb}^{3+}$ be used as sintering aid to enhance the density of the $\operatorname{Pr}$ and $\mathrm{Yb}$ 
dual-doped samples. The HRTEM pattern shows well-resolved interference fringe spacings of $0.24 \mathrm{~nm}$ and $0.27 \mathrm{~nm}$, which agree well with the interplanar distances of the 102 lattice planes and 121 lattice planes, respectively $\left(\mathrm{d}_{102}=2.04 \AA\right.$ and $\mathrm{d}_{121}=2.07 \AA$ based on the powder XRD card 89-0666).
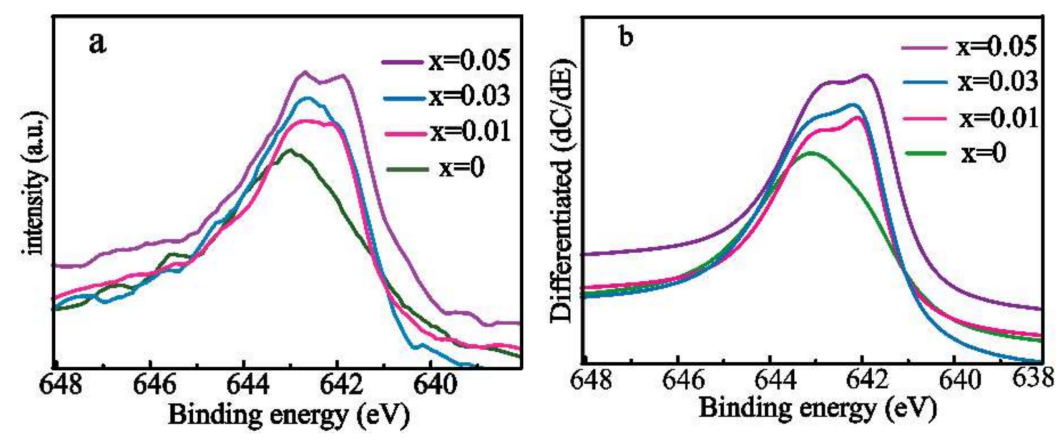

Figure 4. (a) Mn 2p3/2 XPS spectra; (b) differentiated spectra for the $\mathrm{Ca}_{1-2 \mathrm{x}} \mathrm{Pr}_{\mathrm{x}} \mathrm{Yb}_{\mathrm{x}} \mathrm{MnO}_{3}(\mathrm{x}=0,0.01$, 0.03 , and 0.05$)$ series.
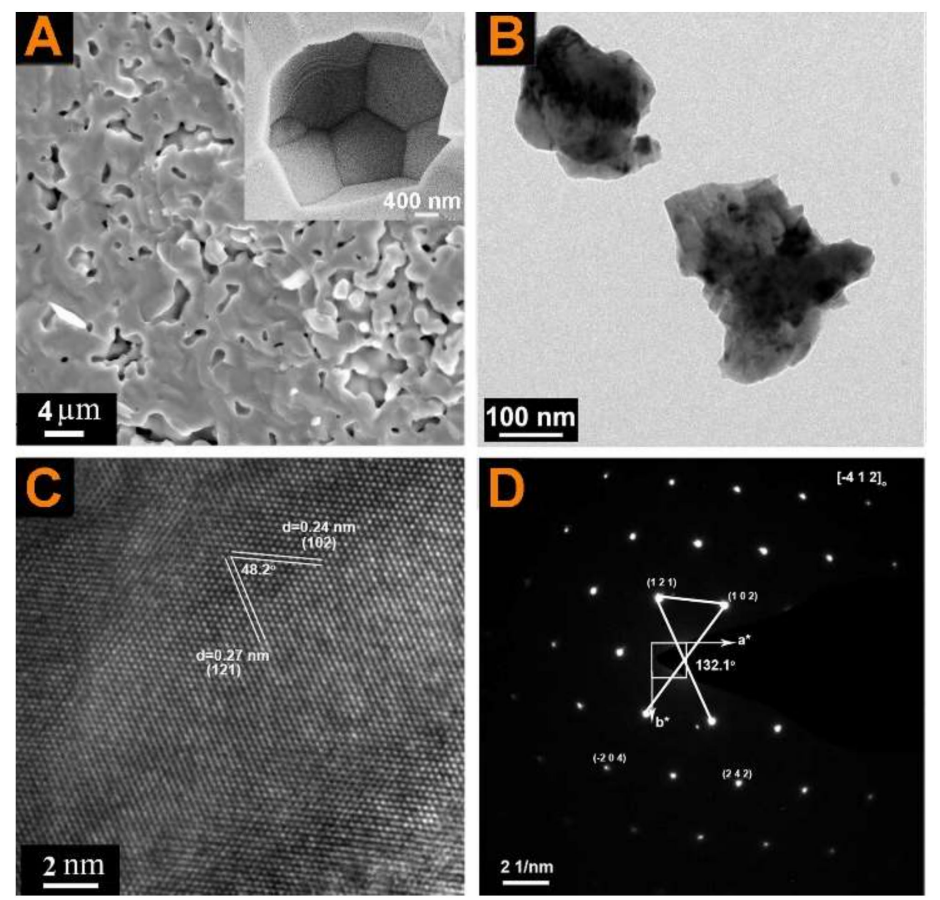

Figure 5. SEM and TEM images of $\mathrm{Ca}_{0.90} \mathrm{Pr}_{0.05} \mathrm{Yb}_{0.05} \mathrm{MnO}_{3}:$ (A) SEM image of bulk;

(B) low-magnification TEM image of powder; (C) high-magnification TEM image of powder; and

(D) electron diffraction pattern of powder.

\subsection{Thermoelectric Properties}

Figure 6a illustrates the temperature dependence of $\rho$ for the $\operatorname{Pr}$ and $\mathrm{Yb}$ dual-doped $\mathrm{Ca}_{1-2 \mathrm{x}} \mathrm{Pr}_{\mathrm{x}} \mathrm{Yb}_{\mathrm{x}} \mathrm{MnO}_{3}(\mathrm{x}=0,0.01,0.02,0.03,0.04$ and 0.05$)$ bulk under temperatures in the range of $300-1000 \mathrm{~K}$. The $\rho$ value of pristine $\mathrm{CaMnO}_{3}$ is initially $4.28 \times 10^{-4} \Omega \mathrm{m}$ and decreases to $2.09 \times 10^{-4} \Omega \mathrm{m}$ as the temperature increases, showing typical semiconductor with $\partial \rho / \partial \mathrm{T}<0$. However, the dual doping of $\mathrm{Pr}$ and $\mathrm{Yb}$ at the Ca site dramatically lowers the $\rho$ value in the $\mathrm{CaMnO}_{3}$ system. The $\rho$ curve temperature dependence of the five dual-doped samples exhibit characteristics of metallic, with $\partial \rho / \partial \mathrm{T}>0$, in which the electrical resistivity increases with increasing temperature. Similar is also found in the single Pr- and $\mathrm{Yb}$-doped $\mathrm{CaMnO}_{3}$. The value of $\rho$ decreases gradually with increasing $\mathrm{Pr}$ and $\mathrm{Yb}$ dual-doping concentrations. The $\mathrm{Ca}_{0.9} \mathrm{Pr}_{0.05} \mathrm{Yb}_{0.05} \mathrm{MnO}_{3}$ show the lowest electrical resistivity. 

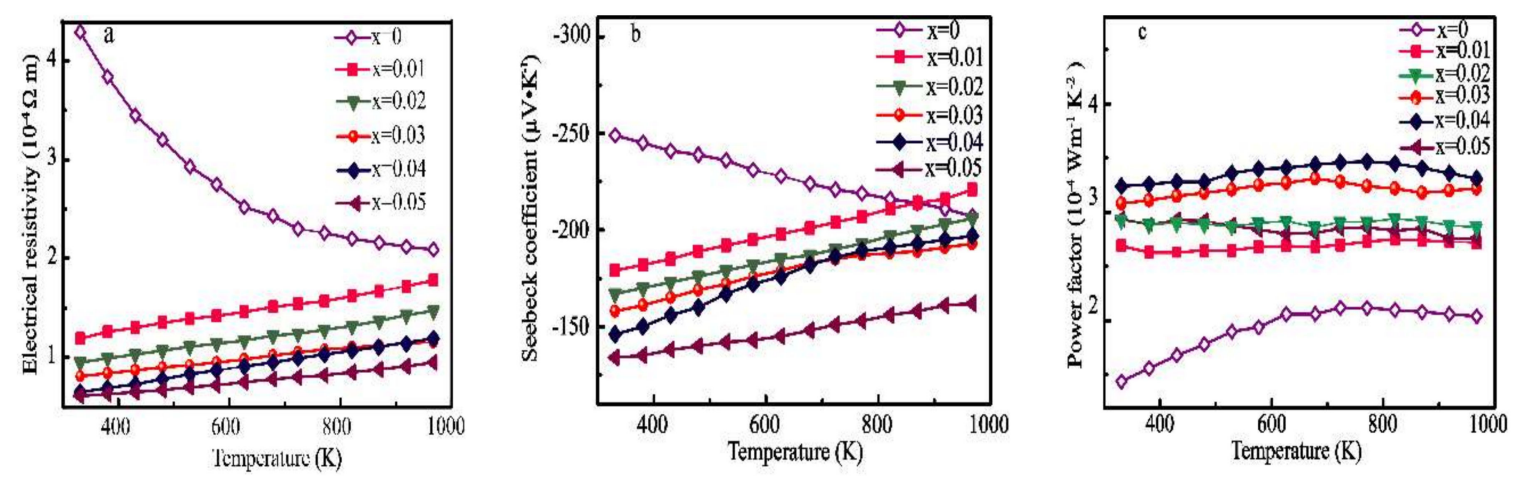

Figure 6. Temperature dependence of (a) the electrical resistivity, $\rho$; (b) the Seebeck coefficient, $S$; and (c) the power factor, PF, for all the samples.

Which is smaller than those of the $\mathrm{Ca}_{0.90} \mathrm{Pr}_{0.1} \mathrm{MnO}_{3}$ and $\mathrm{Ca}_{0.90} \mathrm{Yb}_{0.1} \mathrm{MnO}_{3}$ made through the solid-state process [13,17], confirming that coprecipitation dual doping is more effective than single doping of $\mathrm{Pr}$ or $\mathrm{Yb}$ at the $\mathrm{Ca}$ site. The significant reduction in the dual-doped samples' electrical resistivity can be attributed to the $\mathrm{Mn}^{3+}\left(\mathrm{t}^{3}{ }_{2 \mathrm{~g}} \mathrm{e}^{0} \mathrm{~g}\right)$ cations forming in the $\mathrm{Mn}^{4+}\left(\mathrm{t}^{3}{ }_{2 \mathrm{~g}} \mathrm{e}^{1} \mathrm{~g}\right)$ matrix of $\mathrm{CaMnO}_{3}$ due to dual doping by high-valent $\mathrm{Pr}^{3+}$ and $\mathrm{Yb}^{3+}$ cations at the Ca site, which is further supported by analyses of the above crystal structure and XPS data. An appreciable concentration of $\mathrm{Mn}^{3+}$ is formed as a result of $\mathrm{Pr}^{3+}$ and $\mathrm{Yb}^{3+}$ dual doping at the Ca site, introducing free electrons into the eg orbital. In the eg level, the electrons function as charge carriers in the $\mathrm{Mn}^{3+}-\mathrm{O}-\mathrm{Mn}^{4+}$ framework, reducing $\rho$ with their movement through a hopping mechanism.

The temperature dependence of the Seebeck coefficient of the $\mathrm{Ca}_{1-2 \mathrm{x}} \operatorname{Pr}_{\mathrm{x}} \mathrm{Yb}_{\mathrm{x}} \mathrm{MnO}_{3}(\mathrm{x}=0,0.01$, $0.02,0.03,0.04$ and 0.05 ) is presented in Figure $6 \mathrm{~b}$. The Seebeck coefficient is negative for all samples, indicative of n-type conductive with a dominant electrical carrier. The results demonstrate that the Seebeck coefficient for all the samples possesses a similar dependence on negative temperature. The pristine $\mathrm{CaMnO}_{3}$ show a large Seebeck coefficient, which decreases with increasing temperature as the result of the low carrier concentration of the pristine material. The substitution of the divalent $\mathrm{Ca}^{2+}$ cation by trivalent $\mathrm{Pr}$ and $\mathrm{Yb}$ ions induces the formation of $\mathrm{Mn}^{3+}$ with an eg1 configuration as an electron carrier, resulting in a lower absolute Seebeck coefficient. The absolute Seebeck coefficient can be calculated by the following model proposed for degenerate semiconductors [41]:

$$
\mathrm{S}=\frac{8 \pi^{2} k_{B}^{2}}{3 e h^{2}} m \cdot \mathrm{T}\left(\frac{\pi}{3 n}\right)^{\frac{2}{3}}
$$

where $k_{\mathrm{B}}$ is the Boltzmann constant and $n$ and $m^{*}$ refer to the carrier concentration and the effective mass of the carrier, respectively. The absolute Seebeck coefficient values are inversely proportional to $n$. The Seebeck coefficient decreases with increasing $\operatorname{Pr}$ and $\mathrm{Yb}$ dual-doping concentration, which is attributed to increasing $n$. The absolute value of the Seebeck coefficient gradually decreases when the dual-doping concentration increases, which is in line with the decreasing trend in the electrical resistivity. The absolute Seebeck coefficient decreases from $S_{973 K}=221 \mu \mathrm{V} \cdot \mathrm{K}^{-1}(\mathrm{x}=0.01)$ to $\mathrm{S}_{973 \mathrm{~K}}=162 \mu \mathrm{V} \cdot \mathrm{K}^{-1}(\mathrm{x}=0.05)$ along with an increase in the Pr and $\mathrm{Yb}$ dual-doping concentration.

The PF values of all the samples were obtained through the above $\rho$ and $S$ values and are plotted as a function of temperature in Figure $6 c$. The PF variation in all the samples as a function of temperature is similar to that in $\rho$. In all the samples, PF increases significantly with the increase in the temperature due to the decreased $\rho$ and increased Seebeck coefficient. The PF is inversely proportional to $\rho$ and proportional to the square of the Seebeck coefficient. The trend in the PF in all the samples is approximately similar to that in $\rho$. Initially, PF increases to reach a maximum at $\mathrm{x}=0.04$ and $973 \mathrm{~K}$ and then decreases. The largest PF of $3.48 \times 10^{-4} \mathrm{~W} \cdot \mathrm{m}^{-1} \cdot \mathrm{K}^{-2}$ at $773 \mathrm{~K}$ is obtained for $\mathrm{Ca}_{0.92} \mathrm{Pr}_{0.04} \mathrm{Yb}_{0.04} \mathrm{MnO}_{3}$; this value is approximately two times higher than that obtained for the pristine $\mathrm{CaMnO}_{3}$. Compared to other doped $\mathrm{CaMnO}_{3}$, the PFs obtained in the $\mathrm{Pr}$ and $\mathrm{Yb}$ dual-doped 
$\mathrm{CaMnO}_{3}$ prepared by the coprecipitation method are moderate but much higher than those of the Pr or $\mathrm{Yb}$ single-doped $\mathrm{CaMnO}_{3}$ made through the solid-state process.

The transport properties of a semiconductor are well known to be dominated by the electronic structure close to the Fermi level [6,42]. The theoretically calculated DOS of $\mathrm{CaMnO}_{3}$ and $\mathrm{Ca}_{0.90} \mathrm{Pr}_{0.05} \mathrm{Yb}_{0.05} \mathrm{MnO}_{3}$ are displayed in Figure $7 \mathrm{a}, \mathrm{b}$. The theoretically calculated band gap of the $\mathrm{CaMnO}_{3}$ is $0.70 \mathrm{eV}$, in accordance with the values of previous reports [43,44], indicating that the calculation parameters are reasonable. The dependence of the band gap on the $\mathrm{Pr}$ and $\mathrm{Yb}$ dual-doping concentration is illustrated in Figure 7c. The band gap of the $\mathrm{Pr}$ and $\mathrm{Yb}$ dual-doped $\mathrm{CaMnO}_{3}$ samples decrease with the increasing $\mathrm{Pr}$ and $\mathrm{Yb}$ dual-doping amount. For the $\mathrm{CaPr}_{0.05} \mathrm{Yb}_{0.05} \mathrm{MnO}_{3}$, the theoretically calculated band gap is $0.14 \mathrm{eV}$, which is much lower than that obtained in undoped $\mathrm{CaMnO}_{3}$. The band gap of the $\mathrm{Pr}$ and $\mathrm{Yb}$ dual-doped $\mathrm{CaMnO}_{3}$ is smaller, which is consistent with the experimentally observed reductions in the electrical resistivity and absolute Seebeck coefficient.
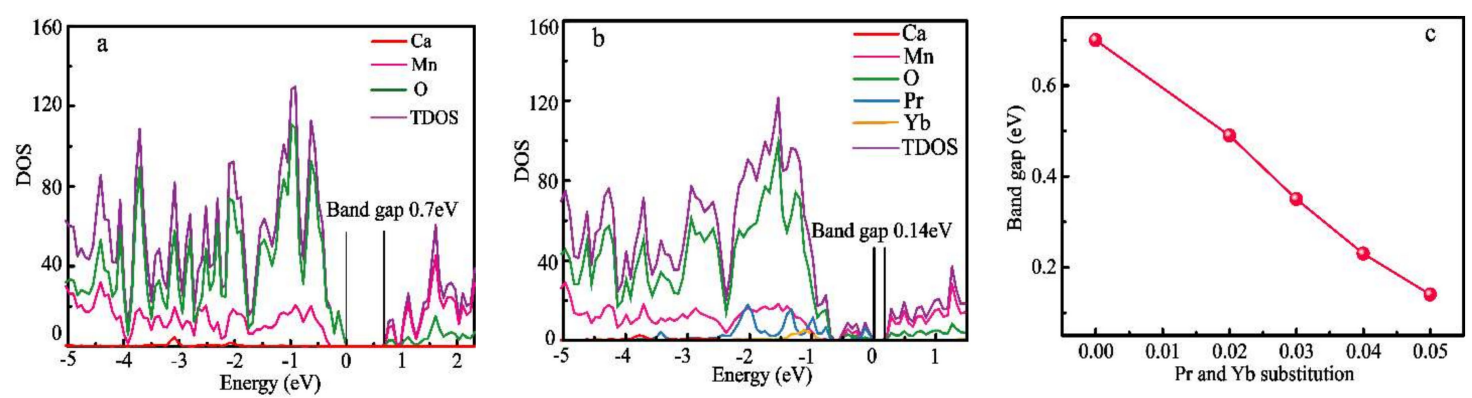

Figure 7. The DOS of (a) $\mathrm{CaMnO}_{3} ;(\mathbf{b}) \mathrm{Ca}_{0.90} \operatorname{Pr}_{0.05} \mathrm{Yb}_{0.05} \mathrm{MnO}_{3}$; and (c) The dependence of the band gap on the $\mathrm{Pr}$ and $\mathrm{Yb}$ dual-doping concentration.

Figure 8a presents the temperature dependence of the total thermal conductivity $\left(\kappa_{\text {total }}\right)$ in all the samples, which tends to decrease with increasing $\mathrm{Pr}$ and $\mathrm{Yb}$ dual-doping concentrations. In addition, the $\kappa_{\text {total }}$ values of the samples produced through the coprecipitation process are much lower than those of the single- and dual-doped samples synthesized by the solid-state process. The decrease in thermal conductivity can be ascribed to enhanced grain boundary scattering. The phonon scattering at the interfaces of the fine-grained samples is strong, which can significantly decrease the thermal conductivity relative to that of the $\mathrm{CaMnO}_{3}$ synthesized by the solid-state process. In general, $\kappa_{\text {total }}$ will be presented as the sum of the electron contribution $\left(\kappa_{\mathrm{e}}\right)$ and the lattice contribution $\left(\kappa_{\mathrm{L}}\right)$ [45]. ke can be estimated from the Wiedemann-Franz law $\left(\kappa_{\mathrm{e}}=\mathrm{LT} / \rho\right)$, in which $\mathrm{L}_{0}$ refers to the Lorentz constant $\left(\mathrm{L}_{0}=2.45 \times 10^{-8} \mathrm{~W} \cdot \Omega \cdot \mathrm{K}^{-2}\right)$. As a result of the decreased electrical resistivity, $\kappa_{\mathrm{e}}$ increases with increasing $\mathrm{Pr}$ and $\mathrm{Yb}$ dual-doping concentrations. According to the Wiedemann-Franz law, the estimated values of $\kappa_{\mathrm{e}}$ are quantitatively small throughout the temperature range and are less than $20 \%$ of $\kappa_{\text {total }}$. Therefore, the contribution of $\kappa_{\mathrm{e}}$ to $\kappa_{\text {total }}$ is negligible, whereas $\kappa_{\mathrm{L}}$ dominates the decrease in the thermal conductivity of the lattice, showing an effective method to improve the TE properties of the perovskite $\mathrm{CaMnO}_{3}$. The changes in $\kappa_{\mathrm{L}}$ as a function of temperature are presented in Figure 8b. From Figure 8b, it can be observed that the lattice thermal conductivity decreases with increasing dual-doping amounts due to the enormous mass difference between the substituting $\operatorname{Pr}$ and $\mathrm{Yb}$ elements and the matrix element $\mathrm{Ca}$ [46] along with the increase in $\mathrm{MnO}_{6}$ distortion. The $\mathrm{MnO}_{6}$ distortion consequently induces structural changes in the overlap place between the $\mathrm{O} 2 \mathrm{p}$ and $\mathrm{Mn} 3 \mathrm{~d}$ orbitals. The change in the electronic structure shown above modifies the thermal transport properties of the $\mathrm{Pr}$ and $\mathrm{Yb}$ dual-doped $\mathrm{CaMnO}_{3}$ series [47]. 

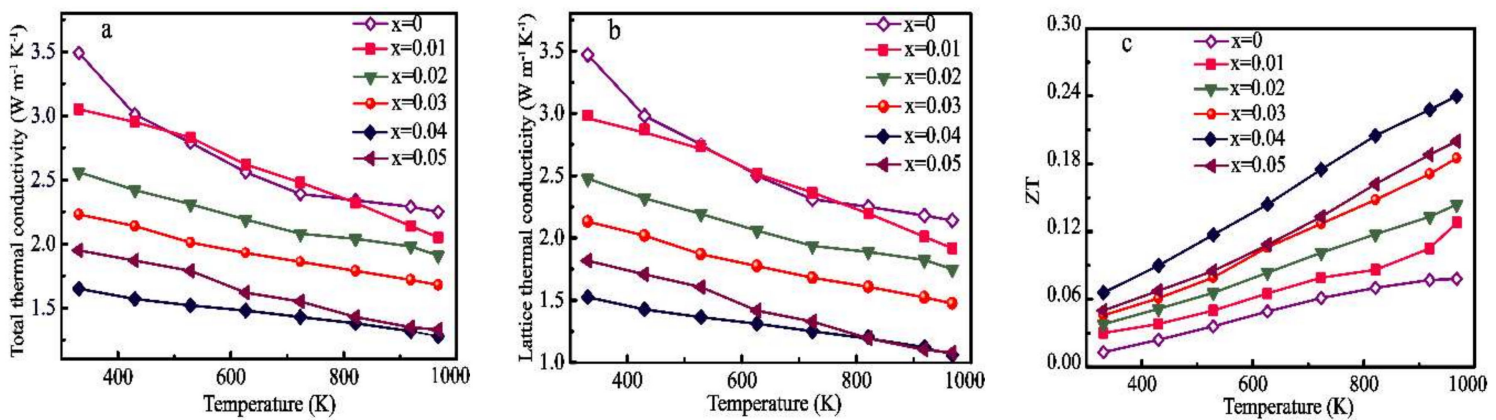

Figure 8. Temperature dependence of (a) total thermal conductivity, $\kappa_{\text {total }}$; (b) lattice thermal conductivity, $\kappa_{\mathrm{L}}$; and (c) ZT for all the samples.

Figure $8 \mathrm{c}$ shows a plot of the ZT value calculated by using the electrical and thermal transport properties over a temperature range of 300-1000 K. The ZT values of all the samples increase as the temperature increases as a result of the two significant decreases in both $\rho$ and $\kappa_{\text {total }}$. The $\operatorname{Pr}$ and $\mathrm{Yb}$ dual-doped samples exhibit significantly better performance than the pristine $\mathrm{CaMnO}_{3}$. In addition, a certain dual-doping concentration $(x=0.04)$ has the largest ZT of 0.24 , which is several times larger than that of the undoped compounds. However, the $\mathrm{ZT}$ value of the $\mathrm{Ca}_{0.92} \mathrm{Pr}_{0.08} \mathrm{MnO}_{3}$ and $\mathrm{Ca}_{0.90} \mathrm{Yb}_{0.10} \mathrm{MnO}_{3}$ prepared by the solid-state method is only $0.16[13,17]$.

\section{Discussion}

A series of $\mathrm{Ca}_{1-2 \mathrm{x}} \mathrm{Pr}_{\mathrm{x}} \mathrm{Yb}_{\mathrm{x}} \mathrm{MnO}_{3}(\mathrm{x}=0,0.01,0.02,0.03,0.04$ and 0.05$)$ were synthesized through the coprecipitation process. The microstructure, electron transport properties and thermal properties of all the samples were studied. The refinement results indicate that the lattice parameters and cell volumes of dual-doped samples increase with increasing $\mathrm{Pr}$ and $\mathrm{Yb}$ dual-doping content, indicating that $\mathrm{Mn}^{3+}$ is formed in the $\mathrm{Mn}^{4+}$ matrix. Moreover, the fact that the increase of the $\mathrm{Mn}^{3+} / \mathrm{Mn}^{4+}$ ratio lead to an increasing in the carrier concentration. This leads to decreased electrical resistivity and a reduced Seebeck coefficient, leading to a maximum PF of $3.48 \times 10^{-4} \mathrm{~W} \cdot \mathrm{m}^{-1} \cdot \mathrm{K}^{-2}$ at $773 \mathrm{~K}$ for the composition $x=0.04$. Our first-principles calculations of the DOS support the experimental findings in terms of the band gap and electrical transport properties. The dual-doping samples prepared by the coprecipitation method possess fine grain size, increasing the scattering of grain boundaries, leading to decreased thermal conductivity for the dual-doped samples. Moreover, structural distortion for $\mathrm{MnO}_{6}$ along with the enormous mass difference between the dual-doping ions and the calcium ions is attributed to the reduction in the thermal conductivity. It was calculated that the highest dimensionless $\mathrm{ZT}$ is 0.24 under the condition of $973 \mathrm{~K}$ in the air for $\mathrm{Ca}_{0.92} \mathrm{Pr}_{0.04} \mathrm{Yb}_{0.04} \mathrm{MnO}_{3}$, and it is 3 times higher than that of the undoped $\mathrm{CaMnO}_{3}$. As a result, the combination of coprecipitation and doping of $\mathrm{Pr}$ and $\mathrm{Yb}$ at the $\mathrm{Ca}$ site is confirmed to effectively promote the TE properties of the $\mathrm{CaMnO}_{3}$.

Author Contributions: Q.C. and Y.Y. conceived the study and designed the experiments; C.L. performed the experiments; Y.Y. computed the electronic structure; C.L. analysed the data and collaborated on the writing the paper; Q.C. and Y.Y. revised the paper.

Funding: This work was supported by the Natural Science Foundation of China (Nos. 21461005 and 21373064), the High-level Innovative Talents Training Project of Guizhou Province (OKHPTRC [2016]5658), the Guizhou Province Graduate Research Fund (KYJJ2017015), the Guizhou Provincial Joint Fund Project (Nos. QKHLH [2017] 7250 and QKHRC [2017] 5788) and the Program for Innovative Research Team of Guizhou Province (No. QKTD [2014]4021).

Conflicts of Interest: The authors declare no conflicts of interest. 


\section{References}

1. Bilen, K.; Ozyurt, O.; Bakırcı, K.; Karslı, S.; Erdogan, S.; Yılmaz, M.; Comaklı, O. Energy production, consumption, and environmental pollution for sustainable development: A case study in Turkey. Renew. Sustain. Energy Rev. 2008, 12, 1529-1561. [CrossRef]

2. Shu, G.Q.; Liang, Y.C.; Wei, H.Q.; Tian, H.; Zhao, J.; Liu, L.N. A review of waste heat recovery on two-stroke IC engine aboard ships. Renew. Sustain. Energy Rev. 2013, 19, 385-401. [CrossRef]

3. He, W.; Zhang, G.; Zhang, X.X.; Ji, J.; Li, G.Q.; Zhao, X.D. Recent development and application of thermoelectric generator and cooler. Appl. Energy 2015, 143, 1-25. [CrossRef]

4. Snyder, G.J.; Toberer, E.S. Complex thermoelectric materials. Nat. Mater. 2008, 7, 105-114. [CrossRef] [PubMed]

5. Heremans, J.P.; Jovovic, V.; Toberer, E.S.; Saramat, A.; Kurosaki, K.; Charoenphakdee, A.; Yamanaka, S.; Snyder, G.J. Enhancement of Thermoelectric Efficiency in PbTe by Distortion of the Electronic Density of States. Science 2008, 321, 553-557. [CrossRef] [PubMed]

6. Zhao, L.D.; Lo, S.H.; Zhang, Y.S.; Sun, H.; Tan, G.G.; Uher, C.; Wolverton, C.; Dravid, V.P.; Kanatzidis, M.G. Ultralow thermal conductivity and high thermoelectric figure of merit in SnSe crystals. Nature 2014, 508, 373-378. [CrossRef] [PubMed]

7. Biswas, K.; He, J.; Blum, I.D.; Chun-IWu; Hogan, T.P.; Seidman, D.N.; Dravid, V.P.; Kanatzidis, M.G. High-performance bulk thermoelectrics with all-scale hierarchical architectures. Nature 2012, 489, 414-418.

8. He, Y.; Lu, P.; Shi, X.; Xu, F.F.; Zhang, T.S.; Snyder, G.J.; Uher, C.; Chen, L.D. Ultrahigh Thermoelectric Performance in Mosaic Crystals. Adv. Mater. 2015, 27, 3639-3644. [CrossRef] [PubMed]

9. Appel, O.; Schwall, M.; Kohne, M.; Balke, B.; Gelbstein, Y. Effects of Microstructural Evolution on the Thermoelectric Properties of Spark-Plasma-Sintered $\mathrm{Ti}_{0.3} \mathrm{Zr}_{0.35} \mathrm{Hf}_{0.35} \mathrm{NiSn}$ Half-Heusler Compound. J. Electron. Mater. 2013, 42, 1340-1345. [CrossRef]

10. Vizel, R.; Bargig, T.; Beeri, O.; Gelbstein, Y. Bonding of $\mathrm{Bi}_{2} \mathrm{Te}_{3}$-Based Thermoelectric Legs to Metallic Contacts Using $\mathrm{Bi}_{0.82} \mathrm{Sb}_{0.18}$ Alloy. J. Electron. Mater. 2016, 45, 1296-1300. [CrossRef]

11. Zhang, F.P.; Lu, Q.M.; Zhang, X.; Zhang, J.X. Electrical transport properties of $\mathrm{CaMnO}_{3}$ thermoelectric compound: A theoretical study. J. Phys. Chem. Solids 2013, 74, 1859-1864. [CrossRef]

12. Ohtaki, M.; Koga, H.; Tokunaga, T.; Eguchi, K.; Arai, H. Electrical Transport Properties and High-Temperature Thermoelectric Performance of $\left(\mathrm{Ca}_{0.9} \mathrm{M}_{0.1}\right) \mathrm{MnO}_{3}(\mathrm{M}=\mathrm{Y}, \mathrm{La}, \mathrm{Ce}, \mathrm{Sm}, \mathrm{In}, \mathrm{Sn}, \mathrm{Sb}, \mathrm{Pb}, \mathrm{Bi})$. J. Solid State Chem. 1995, 120, 105-111. [CrossRef]

13. Flahaut, D.; Mihara, T.; Funahashi, R.; Nabeshima, N.; Lee, K. Thermoelectrical properties of A-site substituted $\mathrm{Ca}_{1-\mathrm{x}} \mathrm{Re}_{\mathrm{x}} \mathrm{MnO}_{3}$ system. J. Appl. Phys. 2006, 100, 084911-1-084911-4. [CrossRef]

14. Wang, Y.; Sui, Y.; Fan, H.G.; Wang, X.J.; Su, Y.T.; Su, W.H.; Liu, X.Y. High Temperature Thermoelectric Response of Electron-Doped $\mathrm{CaMnO}_{3}$. Chem. Mater. 2009, 21, 4653-4660. [CrossRef]

15. Torres, A.S.M.; Madre, M.; Diez, J. Effect of synthesis process on the densification, microstructure, and electrical properties of $\mathrm{Ca}_{0.9} \mathrm{Yb}_{0.1} \mathrm{MnO}_{3}$ ceramics. Int. J. Appl. Ceram. Technol. 2017, 14, 1190-1196.

16. Zhang, F.P.; Niu, B.C.; Zhang, K.S.; Zhang, X.; Lu, Q.M.; Zhang, J.X. Effects of praseodymium doping on thermoelectric transport properties of $\mathrm{CaMnO}_{3}$ compound system. J. Rare Earths 2013, 37, 885-890. [CrossRef]

17. Cong, B.T.; Tsuji, T.; Thao, P.X.; Thanh, P.Q.; Yamamura, Y. High-temperature thermoelectric properties of $\mathrm{Ca}_{1-\mathrm{x}} \mathrm{Pr}_{\mathrm{x}} \mathrm{MnO}_{3-\delta}(0 \leq \mathrm{x}<1)$. Physica B 2004, 352, 352-357.

18. Soteloa, A.; Depriesterb, M.; Torresa, M.A.; Sahraouib, A.H.; Madrea, M.A.; Dieza, J.C. Effect of simultaneous $\mathrm{K}$, and $\mathrm{Yb}$ substitution for $\mathrm{Ca}$ on the microstructural and thermoelectric characteristics of $\mathrm{CaMnO}_{3}$ ceramics. Ceram. Int. 2017, 44, 12697-12701. [CrossRef]

19. Zhu, Y.H.; Su, W.B.; Liu, J.; Zhou, Y.C.; Li, J.; Zhang, X.; Du, Y.; Wang, C.L. Effects of Dy and Yb co-doping on thermoelectric properties of $\mathrm{CaMnO}_{3}$ ceramics. Ceram. Int. 2015, 41, 1535-1543. [CrossRef]

20. Wang, Y.; Sui, Y.; Wang, X.; Su, W. Enhancement of thermoelectric efficiency in (Ca,Dy) $\mathrm{MnO}_{3}-(\mathrm{Ca}, \mathrm{Yb}) \mathrm{MnO}_{3}$ solid solutions. Appl. Phys. Lett. 2010, 97, 4. [CrossRef]

21. Kosuga, A.; Isse, Y.; Wang, Y.; Koumoto, K.; Funahashi, R. High-temperature thermoelectric properties of Ca 0.9-x $\mathrm{Sr}_{\mathrm{x}} \mathrm{Yb}_{0.1} \mathrm{MnO}_{3}$. J. Appl. Phys. 2009, 105, 093717-1-093717-6. [CrossRef]

22. Kim, C.M.; Seo, J.W.; Cha, J.S.; Park, K. Electrical transport properties of $\mathrm{Ca}_{0.9} \mathrm{La}_{0.1-\mathrm{x}} \mathrm{Bi}_{\mathrm{x}} \mathrm{MnO}_{3-\delta}$ $(0 \leq \mathrm{x} \leq 0.1)$ thermoelectric materials. Int. J. Hydrogen Energy 2015, 40, 15556-155568. [CrossRef] 
23. Wang, H.C.; Wang, C.L. Synthesis of Dy doped $\mathrm{Yb}_{0.1} \mathrm{Ca}_{0.9} \mathrm{MnO}_{3}$ ceramics with a high relative density and their thermoelectric properties. Mater. Res. Bull. 2012, 47, 2252-2256. [CrossRef]

24. Löhnert, R.; Stelter, M.; Töpfer, J. Evaluation of soft chemistry methods to synthesize Gd-doped $\mathrm{CaMnO}_{3-\delta}$ with improved thermoelectric properties. Mater. Sci. Eng. B 2017, 223, 185-193. [CrossRef]

25. Rodriguez-Carvajal, J.; Fullprof, K. Version 4.6 c-Mar 2002. Physica B 1993, 192, 55-69.

26. Taguchi, H.; Sonoda, M.; Nagao, M. Relationship between Angles for Mn-O-Mn and Electrical Properties of Orthorhombic Perovskite-Type $\left(\mathrm{Ca}_{1-\mathrm{x}} \mathrm{Sr}_{\mathrm{x}}\right) \mathrm{MnO}_{3}$. J. Solid State Chem. 1998, 137, 82-86. [CrossRef]

27. Giesber, H.G.; Pennington, W.T.; Kolis, J.W. Redetermination of $\mathrm{CaMn}_{2} \mathrm{O}_{4}$. Acta Crystallogr. Sect. C Cryst. Struct. Commun. 2001, C57, 329-330. [CrossRef]

28. Li, C.Q.; Chen, Q.L.; Yan, Y.A.; Li, Y.N.; Zhao, Y. High-temperature thermoelectric properties of $\mathrm{Ca}_{0.92} \mathrm{La}_{0.04} \mathrm{RE}_{0.04} \mathrm{MnO}_{3}(\mathrm{RE}=\mathrm{Sm}$, Dy and $\mathrm{Yb})$ prepared by coprecipitation. Mater. Res. Express 2018. [CrossRef]

29. VandeVondele, J.; Krack, M.; Mohamed, F.; Parrinello, M.; Chassaing, T.; Hutter, J. QUICKSTEP: Fast and accurate density functional calculations using a mixed Gaussian and plane waves approach. Comput. Phys. Commun. 2005, 167, 103-128. [CrossRef]

30. Perdew, J.P.; Burke, K.; Ernzerhof, M. Generalized Gradient Approximation Made Simple. Phys. Rev. Lett. 1996, 77, 3865-3868. [CrossRef] [PubMed]

31. Goedecker, S.; Teter, M.; Hutter, J. Separable dual-space Gaussian pseudopotentials. Phys. Rev. B 1996, 54, 1703-1709. [CrossRef]

32. VandeVondele, J.; Hutter, J. Gaussian basis sets for accurate calculations on molecular systems in gas and condensed phases. J. Chem. Phys. 2007, 127, 114105-1-114105-9. [CrossRef] [PubMed]

33. Shannon, R.D. Revised effective ionic radii and systematic studies of interatomic distances in halides and chalcogenides. Acta Crystallogr. E 1976, 32, 751-767. [CrossRef]

34. Zhun, Y.; Wang, C.; Su, W.; Li, J.; Liu, J.; Du, Y.; Mei, L. High-temperature thermoelectric performance of $\mathrm{Ca}_{0.96} \mathrm{Dy}_{0.02} \mathrm{RE}_{0.02} \mathrm{MnO}_{3}$ ceramics ( $\left.\mathrm{R}=\mathrm{Ho}, \mathrm{Er}, \mathrm{Tm}\right)$. Ceram. Int. 2014, 40, 15531-15536.

35. Bocher, L.; Aguirre, M.H.; Logvinovich, D.; Shkabko, A.; Robert, R.; Trottmann, M.; Weidenkaff, A. $\mathrm{CaMn}_{1-\mathrm{x}} \mathrm{Nb}_{\mathrm{x}} \mathrm{O}_{3}(\mathrm{x} \leq 0.08)$ Perovskite-Type Phases as Promising New High-Temperature n-Type Thermoelectric Materials. Inorg. Chem. 2008, 47, 8077-8085. [CrossRef] [PubMed]

36. Granado, E.; Moreno, N.O.; Martinho, H.; García, A.; Sanjurjo, J.A.; Rettori, I.T.C.; Neumeier, J.J.; Oseroff, S.B. Dramatic Changes in the Magnetic Coupling Mechanism for La-Doped $\mathrm{CaMnO}_{3}$. Phys. Rev. Lett. 2001, 86, 5385-5388. [CrossRef] [PubMed]

37. Jahn, H.A.; Teller, E. Stability of Polyatomic Molecules in Degenerate Electronic States I-Orbital Degeneracy. Proc. R. Soc. Lond. Ser. A 1937, 161, 220-235. [CrossRef]

38. Bocher, L.; Aguirre, M.H.; Robert, R.; Logvinovich, D.; Bakardjieva, S.; Hejtmanek, J.; Weidenkaff, A. High-temperature stability, structure and thermoelectric properties of $\mathrm{CaMn}_{1-\mathrm{x}} \mathrm{Nb}_{\mathrm{x}} \mathrm{O}_{3}$ phases. Acta Mater. 2009, 57, 5667-5680. [CrossRef]

39. Wei, Y.G.; Kim, K.-B.; Chen, G. Evolution of the local structure and electrochemical properties of spinel $\mathrm{LiNi}_{\mathrm{x}} \mathrm{Mn}_{2-\mathrm{x}} \mathrm{O}_{4}(0 \leq \mathrm{x} \leq 0.5)$. Electrochim. Acta 2006, 51, 3365-3373. [CrossRef]

40. Zhan, B.; Lan, J.L.; Liu, Y.C.; Lin, Y.H.; Shen, Y.; Nan, C.W. High Temperature Thermoelectric Properties of Dy-doped $\mathrm{CaMnO}_{3}$ Ceramics. J. Mater. Sci. Technol. 2014, 30, 821-825. [CrossRef]

41. Zhang, B.Y.; Wang, J.; Zou, T.; Zhang, S.; Yaer, X.B.; Ding, N.; Liu, C.Y.; Miao, L.; Li, Y.; Wu, Y. High thermoelectric performance of $\mathrm{Nb}$-doped $\mathrm{SrTiO}_{3}$ bulk materials with different doping levels. J. Mater. Chem. C 2015. [CrossRef]

42. Zhang, F.P.; Zhang, X.; Lu, Q.M.; Zhang, J.X.; Liu, Y.Q.; Fan, R.F.; Zhang, G.Z. Doping induced electronic structure and estimated thermoelectric properties of $\mathrm{CaMnO}_{3}$ system. Phys. B Condens. Matter 2011, 406, 1258-1262. [CrossRef]

43. Zhang, X.H.; Li, J.C.; Du, Y.L.; Wang, F.N.; Liu, H.Z.; Zhu, Y.H.; Liu, J.; Su, W.B.; Wang, C.L.; Mei, L.M. Thermoelectric properties of A-site substituted Lanthanide $\mathrm{Ca}_{0.75} \mathrm{R}_{0.25} \mathrm{MnO}_{3}$. J. Alloys Compd. 2015, 634, 1-5. [CrossRef]

44. Zhang, F.P.; Zhang, X.; Lu, Q.M.; Zhang, J.X.; Liu, Y.Q. Electronic structure and thermal properties of doped $\mathrm{CaMnO}_{3}$ systems. J. Alloys Compd. 2011, 509, 4171-4175. [CrossRef]

45. Kabir, R.; Zhang, T.; Wang, D.; Donelson, R.; Tian, R.; Tan, T.T.; Li, S. Improvement in the thermoelectric properties of $\mathrm{CaMnO}_{3}$ perovskites by W doping. J. Mater. Sci. 2014, 49, 7522-7528. [CrossRef] 
46. Wang, Y.; Sui, Y.; Su, W. High temperature thermoelectric characteristics of $\mathrm{Ca}_{0.9} \mathrm{R}_{0.1} \mathrm{MnO}_{3}(\mathrm{R}=\mathrm{La}, \mathrm{Pr}, \ldots$, Yb). J. Appl. Phys. 2008, 104, 093703-093703-7. [CrossRef]

47. Wang, Y.; Sui, Y.; Wang, X.; Su, W.; Liu, X.; Fan, H.J. Thermal conductivity of electron-doped $\mathrm{CaMnO}_{3}$ perovskites: Local lattice distortions and optical phonon thermal excitation. Acta Mater. 2010, 58, 6306-6316. [CrossRef] 